\title{
Production Potential and Economics of Fodder Maize (Zea mays) Varieties Sown under Varying Intercropping Systems with Cowpea (Vigna unguiculata)
}

\author{
Sapna Bhagat*, Meenakshi Gupta, Monika Banotra, Arpita Sharma, \\ Sandeep Kumar and Ashu Sharma
}

\author{
Department of Agronomy, Sher-e-Kashmir University of Agricultural \\ Sciences and Technology, Jammu-180009, India \\ *Corresponding author
}

\section{A B S T R A C T}

The field experiment was conducted during Zaid season of 2014 to study the Production Potential and Economics of Fodder Maize (Zea mays) Varieties Sown under Varying Intercropping Systems with Cowpea (Vigna unguiculata), at the Research Farm of

Keywords

Economics, Fodder, Intercropping, Yield.

Article Info

Accepted:

28 November 2017

Available Online:

10 December 2017
Division of Agronomy, Sher-e-Kashmir University of Agricultural Sciences and Technology of Jammu. The treatments include three fodder maize cultivars (African tall, J1006 and local variety) and cowpea (CL-367) were sown in sole crop as well as in intercropping systems consisting of sixteen treatments in Randomized block design replicated thrice. Among the sole varieties significantly highest green biomass yield, dry biomass yield, net returns and $\mathrm{B}$ : $\mathrm{C}$ ratio was recorded with African tall followed by Sole J-1006 whereas among intercropping treatments significantly the highest fodder maize green biomass and yield, net returns and b: c ratio was recorded with African tall intercropped with cowpea in 2:1 row ratio. Therefore, African tall variety of fodder maize as sole and African tall variety of fodder maize intercropped with cowpea in 2:1 row ratio was found best for increasing yield potential and economics of fodder maize in different intercropping systems.

\section{Introduction}

Maize (Zea mays), among the different fodder crops is regarded as one of the important dual purpose crop, used in human diet as well as animal feed. Maize has the potential to supply large amounts of energy-rich forage for daily animal diets and its fodder can safely be fed at all stages of growth without any danger of oxalic acid, prussic acid as in case of sorghum (Dahmardeh et al., 2009). Thus, forage maize has become a major constituent of ruminant rations in recent years, as its inclusion as dairy cow diets improves forage intake, increases animal performance and reduces production costs (Anil et al., 2000 and Cusicanqui and Lauer, 1999). Although maize provides high yield in terms of dry matter, it produces forage with low protein content. However, protein is needed by livestock for growth and milk production. Protein is also needed by rumen bacteria which digest much of the feed for ruminant animals (Ghanbari, 2000).besides the requirement of the animal is to high and hence to balance the protein production and consumption within a unit amount of land is the need of the therefore legume as an intercrop with maize can help us 
to generate more fresh fodder and protein yield. Among different legumes as intercrop Cowpea (Vigna unguiculata), an annual legume with high level of protein (about two times more than maize), can be mixed with maize to improve forage protein content of diets and thus, the cost of high quality forage production can be lowered. It is capable of fixing nitrogen in association with rhizobium bacteria. Thus for improving the nitrogen status of soil, cowpea could be grown best on well drained soils of moderate to high fertility, such as homestead fields, or top land fields with a history of manure or fertilizer application. In low phosphorus field, the benefits from the cowpea are reduced.

Growing of two or more crop species simultaneously in the same field during a growing season is defined as intercropping (Ofori and Stern, 1987), has many advantages over sole cropping. It provides an efficient utilization of environmental resources, reduces risk of the cost of production, provides greater financial stability for farmers, decreases pest damages, suppresses weed growth more than monocultures, improves soil fertility through increased $\mathrm{N}$ content and improves forage yield and quality (Francis et al., 1976 and Willey, 1979). Many researchers have explored the use of intercropping for forage production. Toniolo et al., (1987) reported significantly higher crude protein content of maize-pulse intercropping than that of mono-cropped maize. Fodder cowpea when mixed with fodder maize increases the protein content and tonnage of fodder with higher palatability. Cereal fodder-legume intercropping plays an important role in subsistence food production in both developed and developing countries, especially in situations of limited water resources. Intercropping of cereal fodder and legume crops helps to maintain and improve soil fertility. Legumes fix atmospheric nitrogen, which may be utilized by the host plant or may be excreted from the nodules into the soil and be used by other plants growing nearby. Legumes can also transfer fixed $\mathrm{N}$ to intercropped cereals during their joint growing period and this $\mathrm{N}$ is an important resource for the cereals. Besides increasing the ecological and economic diversity, intercropping brings an increase in production or yield benefits, more efficient use of water resources, land, nutrients and labours, reduction in problems caused by pests, diseases and weeds (Awal et al., 2006). Intercropping may also lead to increased production per unit area per unit time without affecting the yield of main crop to a greater extent.

Supply of forage is inadequate in the country not only in terms of quality but also in quantity. Since the scope of area expansion under fodder cultivation (5 per cent of cultivable area) is limited, the productivity of fodder crops is to be raised through best utilization of the resources of the prevailing production systems. Intercropping of botanically diverse forage species like cereals and legumes appear to be one of the feasible approaches for increasing the herbage yield, utilization of land more efficiently, improving the forage quality and providing stability to production (Tripathi, 1989).

\section{Materials and Methods}

A field experiment was conducted during Zaid 2014 at the Research Farm of Division of Agronomy, Sher-e-Kashmir University of Agricultural Sciences and Technology ofJammu (Jammu and Kashmir) situated at $32^{\circ} 39^{\prime} \mathrm{N}$ latitude and $74^{\circ} 53^{\prime} \mathrm{E}$ longitude at an elevation of 332 meter above mean sea level. The research farm of the Division of Agronomy comes under the subtropicalirrigated Shiwalik foothill zone. The soil of the experimental site was sandy clay loam in texture. The soil was slightly alkaline in $\mathrm{pH}$ (7.31) with electrical conductivity in the safer 
range $\left(0.19 \mathrm{dsm}^{-1}\right)$, low in organic carbon (0.37) and available $\mathrm{N}(245.78 \mathrm{~kg} / \mathrm{ha})$ but medium in available phosphorus (13.26 $\mathrm{kg} / \mathrm{ha})$ and potassium (144.26 kg/ha). The experiment was laid out in randomized block design with three replications and comprising Sixteen treatment combinations with three fodder maize cultivars "African tall, J-1006 and local variety" and cowpea "CL-367" were sown as sole crop as well as in intercropping systems. The net plot area was $3.0 \times 2.20 \mathrm{~m}$ with spacing $30 \times 15 \mathrm{~cm}$. The recommended doses of $\mathrm{N}(50 \mathrm{~kg}), \mathrm{P}_{2} \mathrm{O}_{5}(24 \mathrm{~kg})$ and $\mathrm{K}_{2} \mathrm{O}(12$ $\mathrm{kg}$ ) were applied in the form of urea, diammonium phosphate and muriate of potash, respectively.

Half of the dose of $\mathrm{N}$ and whole amount of $\mathrm{P}$ and $\mathrm{K}$ was applied as basal and the remaining half dose of nitrogen was applied at 25 days interval. The treatment wise green biomass yield was taken from the each net plot and averaged to get green biomass yield per plot whereas for dry biomass yield samples drawn for dry matter accumulation studies at harvest were utilized for calculating dry biomass yield.The fresh weight of the samples were recorded and dried in hot air oven at $75^{\circ} \mathrm{C}$ for 48-72 hours to record the dry weight. Plotwise green biomass yield was multiplied by respective dry matter percentage to get dry weight in kg per plot and was expressed dry biomass yield in $\mathrm{q} / \mathrm{ha}$.

\section{Economics}

\section{Cost of cultivation}

The total cost of cultivation (Rs/ha) of each treatment is calculated on per hectare basis. The wages of labour, amount spent on mechanical power for different operations and cost of inputs such as seed, fertilizers, herbicide and pesticides were calculated on the basis of the then prevailing market rate of the respective items.

\section{Gross returns}

Gross returns (Rs/ha) were worked out by multiplying the saleable products (Stover) of the different cultivars of fodder maize and cowpea by their then prevailing sale rates.

\section{Net returns}

Net returns (Rs/ha) were calculated by deducting the cost of cultivation from the gross returns.

Net returns $=$ Gross returns - Cost of cultivation

\section{Benefit-Cost ratio}

Benefit-Cost ratio of different treatments was calculated by using the formula:

Benefit $:$ Cost ratio $=\frac{\text { Net returns }}{\text { Total cost of cultivation }}$

\section{Results and Discussion}

\section{Green biomass yield and dry biomass yield}

Fodder maize cultivars varied significantly with regard to green biomass and dry biomass yield.Among different sole fodder cultivars, African tall as a sole crop recorded green biomass yield of $211.93 \mathrm{q} / \mathrm{ha}$ and was statistically at par with sole maize cultivar J1006 (205.90 q/ha); whereas sole cowpea cultivar (CL-367) recorded significantly lowest green biomass yield of $165.29 \mathrm{q} / \mathrm{ha}$ whereas among various sole fodder maize cultivars and intercropping treatments increased the dry biomass yield of crop up to harvest. Among the fodder maize cultivars, African tall recorded highest dry biomass yield $48.16 \mathrm{q} / \mathrm{ha}$ at harvest which was followed by sole $\mathrm{J}-1006$ (46.21 q/ha) and sole local variety $45.56 \mathrm{q} / \mathrm{ha}$, Whereas dry biomass of sole cowpea was recorded $36.34 \mathrm{q} / \mathrm{ha}$ 
which was lower to all fodder maize cultivars. These yield differences were attributed to differences in the growth cycles of the cultivar. Cultivar African tall produced higher fresh and dry biomass yield which might be due to more growth as indicated by its greater height. Similar results were also reported by Patil et al., (1996) while studying the yielding ability of forage maize genotypes in mixed cropping with cowpea.

The data on mean green biomass yield revealed that different sole fodder cultivars and intercropping treatments differed significantly from each other. In intercropping treatments, African tall intercropped with cowpea in 2:1 ratio recorded significantly highest green biomass yield (293.84 q/ha) which was found at par with African tall intercropped with cowpea in 2:1 seed mix and $\mathrm{J}-1006$ intercropped with cowpea in $2: 1$ ratio producing 285.00 and $279.64 \mathrm{q} / \mathrm{ha}$ of green biomass. However, lowest green biomass yield was observed with local variety intercropped with cowpea in 2:1 seed mix (137.16 q/ha) which remained statistically at par with the local variety intercropped with cowpea in 1:1 row ratio (131.80 q/ha).

The dry biomass accumulation is an important growth index to assess the performance of crop under the influence of different treatments. The data on dry matter production observed at harvest is presented in Table 1 revealed that dry matter yield continued to increase with the advancement in crop age and the increase was observed up to harvest. Among the various intercropping treatments significantly maximum dry biomass yield to the tune of $72.01 \mathrm{q} / \mathrm{ha}$, was recorded with the African tall intercropped with cowpea in 2:1 row ratio which was at par with African tall intercropped with cowpea in $2: 1$ as well as 1:1 seed mix (70.07 and $64.17 \mathrm{q} / \mathrm{ha}$ ).

Table.1 Effect of different cultivars and intercropping systems on green biomass and dry biomass yield (q/ha) of fodder maize and cowpea

Sole African Tall
Sole J-1006
Sole local variety
Sole cowpea var. CL-367
African Tall + cowpea $(1: 1)$
African Tall + cowpea $(2: 1)$
African Tall + cowpea $(1: 1$ mix $)$
African Tall + cowpea $(2: 1$ mix $)$
J-1006 + cowpea $(1: 1)$
J-1006 + cowpea $(2: 1)$
J-1006 + cowpea $(1: 1$ mix $)$
J-1006 + cowpea $(2: 1$ mix $)$
Local variety + cowpea $(1: 1)$
Local variety + cowpea $(2: 1)$
Local variety + cowpea $(1: 1$ mix $)$
Local variety + cowpea $(2: 1$ mix $)$
SEm \pm$)$
LSD $(p=0.05)$

Sole African Tall

Sole J-1006

Sole local variety

Sole cowpea var. CL-367

African Tall + cowpea (1:1)

African Tall + cowpea $(2: 1)$

African Tall + cowpea $(2: 1$ mix $)$

wea $(1: 1)$

J-1006 + cowpea $(1: 1 \mathrm{mix})$

J-1006 + cowpea $(2: 1$ mix $)$

Local variety + cowpea $(1: 1)$

Local variety + cowpea $(2: 1)$

Local variety + cowpea (1:1 mix)

$\operatorname{SEm}(+)$
Green Biomass Yield

(q/ha)

211.93

205.90

185.33

165.29

270.65

293.84

263.35

285.00

249.64

279.64

274.04

252.41

236.80

265.69

247.92

232.40

5.21

15.12
Dry Biomass Yield

(q/ha)

48.16

46.21

45.56

36.34

69.49

72.01

64.17

70.07

54.60

64.50

53.02

57.48

46.51

55.86

43.76

52.99

3.14

9.12 
Table.2 Effect of different cultivars and intercropping systems on relative economics of fodder maize and cowpea

\begin{tabular}{lcccc}
\hline \multicolumn{1}{c}{ Treatments } & $\begin{array}{c}\text { Cost of Cultivation } \\
\text { (R s. /ha) }\end{array}$ & $\begin{array}{c}\text { Gross Returns } \\
\text { (R s. /ha) }\end{array}$ & $\begin{array}{c}\text { Net Returns } \\
\text { (R s. /ha) }\end{array}$ & $\begin{array}{c}\text { B:C } \\
\text { Ratio }\end{array}$ \\
\hline Sole African Tall & 12964 & 38148 & 25185 & 1.94 \\
Sole J-1006 & 12814 & 37062 & 24249 & 1.89 \\
Sole local variety & 12314 & 33300 & 20987 & 1.70 \\
Sole cowpea var. CL-367 & 13414 & 29700 & 16287 & 1.21 \\
African Tall + cowpea (1:1) & 18055 & 48717 & 30663 & 1.69 \\
African Tall + cowpea (2:1) & 15509 & 52892 & 37383 & 2.41 \\
African Tall + cowpea(1:1 mix) & 18280 & 47403 & 29124 & 1.59 \\
African Tall + cowpea(2:1 mix) & 15734 & 51300 & 35567 & 2.26 \\
J-1006 + cowpea (1:1) & 17905 & 44936 & 27031 & 1.50 \\
J-1006 + cowpea (2:1) & 15359 & 49436 & 34077 & 2.21 \\
J-1006 + cowpea (1:1 mix) & 18205 & 45434 & 27230 & 1.49 \\
J-1006 + cowpea (2:1 mix) & 15659 & 47825 & 32166 & 2.05 \\
Local variety + cowpea (1:1) & 17155 & 42464 & 25470 & 1.48 \\
Local variety + cowpea (2:1) & 14609 & 44626 & 30017 & 2.05 \\
Local variety + cowpea (1:1 mix) & 17830 & 41832 & 24003 & 1.34 \\
Local variety + cowpea (2:1 mix) & 15284 & 44077 & 28793 & 1.88 \\
\hline
\end{tabular}

African tall intercropped with cowpea in 1:1 row ratio was $69.49 \mathrm{q} / \mathrm{ha}$ and $\mathrm{J}-1006$ intercropped with cowpea in $2: 1$ row ratio was $64.50 \mathrm{q} / \mathrm{ha}$. In the intercropping systems the green biomass and dry biomass yield were found highest for African tall intercropped with cowpea in 2:1 row ratio followed by $2: 1$ seed mix due to higher plant height, number of leaves in 2:1 as compare to $1: 1$ row ratio and 1:1 seed mix which contributed ultimately to higher yield along with the exploitation of different resources from various soil layers without competing with each other. Similar results were also reported by Sharma et al., (2008).

\section{Economics}

The practicability and usefulness of treatments is judged ultimately in terms of net returns. The economics worked out at maturity revealed that net returns and benefit cost ratio were affected by different cultivars. Treatment wise economic returns were worked out with the help of operating cost of individual treatment and the cost of production. Among the cultivars, net returns (Rs. 25184.15/ha) were found to be highest in sole fodder maize cultivar African tall with B: $\mathrm{C}$ ratio of 1.94 followed by sole J-1006 with net returns of Rs. 24248.75/ha and B: C ratio of 1.89. At harvest, the difference in net returns and benefit cost ratio was might be due to variation in yield. These finding are in accordance with those of with Sahoo and Mahapatra (2007), Oplanic et al., (2008) and Williams (2008) (Table 2).

Among the different intercropping treatments highest net returns (Rs.37382.00/ha) and B:C ratio (2.14) were obtained in African tall intercropped with cowpea in 2:1 row ratio followed by 1:1 ratio of the same intercropping system.

Significantly lowest value of net returns (Rs. 24002.31/ha) and B: C ratio (1.34) was obtained by local variety of fodder maize intercropped with cowpea in 1:1 seed mix, respectively. This variation might be due to higher yields resulting from difference in dry matter and number of plant $/ \mathrm{m}^{2}$. Srivasulu et 
al., (2008) also reported the economic viability of intercropping than sole cropped maize.

\section{References}

Anil, L., Park, J. and Phipps, R.H. 2000. The Potential of Forage-Maize Intercrops in Ruminant Nutrition. Animal Feed Science and Technology, 85: 157-164.

Awal, M.A., Koshi, H. and Ikeda, T. 2006. Radiation interception and use by maize/peanut intercrop canopy. Agricultural and Forest Meteorology, 139: 74-83.

Cusicanqui, A. and Lauer, J.G. 1999. Plant density and hybrid influenced on corn forage yield and quality. Agronomy Journal, 91: 911-915.

Dahmardeh, M., Ghanbari, A., Syasar, B. and Ramroudi, M. 2009. Effect of intercropping maize with cowpea on green forage yield and quality evaluation. Asian Journal of Plant Science, 8(3): 235-239.

Francis, C.A., Flor, C.A. and Temple, S.R. 1976. Adapting varieties for intercropping system in the Tropics. American Society of Agronomy, 27: 235-253.

Ghanbari, B.A. 2000. Intercropped wheat and bean as a low-input forage. Ph.D Thesis. Wye College, University of London.

Ofori, F. and Stern, W.R. 1987. Cereallegume intercropping systems. Advances in Agronomy. 41: 41-90.

Oplanic, M., Silvana, A., Persuric, I., Rozam, L. and Znidarcic, D. 2008. Economic analysis of different Sweet corn varities production. Stara Lesna, Slovakia.

Patil, T.C., Prabhakar, A.S. and Meli, S.S. 1996. Yield ability of forage maize genotypes in mixed cropping with cowpea. Karnataka Journal of Agricultural Sciences, 8(3): 382-384.

Sahoo, S.C. and Mahapatra, P.K. 2007. Response of Sweet corn to plant population and fertility levels during rabi. Indian Journal of Agricultural Sciences, 77(11): 779-781.

Sharma, R.P., Singh, A.K, Poddar, B.K. and Raman, K.R. 2008. Forage Production Potential and Economics of Maize (Zea mays) with Legumes Intercropping under Various Row Proportions. Indian Journal of Agronomy, 53(2): 121-124.

Srinivasulu, A., Sagar, G.K., Chandriika, V. and Reddy, D.S. 2008. Performance of maize genotype under varied time of sowing under rain fed conditions in the Southern Agro-climatic zone of Andhra Pradesh. 28(3): 233-234.

Toniolo, L., Sattin, M. and Mosca, G. 1987. Soybean-Maize Intercropping for Forage. Eurosoya, 5: 73-78.

Tripathi, S.N. 1989. Mixed cropping of forage species in relation to herbage yield and quality. Indian Journal of Dryland Agricultural Research and Development, 4(2): 68-72.

Williams, M.M.II. 2008. Sweet corn growth and yield responses to planting dates of north and central United States. Horticulture Science, 43(6): 1775-1779.

\section{How to cite this article:}

Sapna Bhagat, Meenakshi Gupta, Monika Banotra, Arpita Sharma, Sandeep Kumar and Ashu Sharma. 2017. Production Potential and Economics of Fodder Maize (Zea mays) Varieties Sown under Varying Intercropping Systems with Cowpea (Vigna unguiculata). Int.J.Curr.Microbiol.App.Sci. 6(12): 4082-4087. doi: https://doi.org/10.20546/ijcmas.2017.612.469 